International Business and Global Economy 2018, no. 37, pp. 128-141

Biznes międzynarodowy w gospodarce globalnej 2018, nr 37, s. 128-141

Edited by the Institute of International Business, University of Gdańsk

ISSN 2300-6102

e-ISSN 2353-9496

DOI 10.4467/23539496IB.18.009.9382

Edward Molendowski ${ }^{1}$

Uniwersytet Ekonomiczny w Krakowie

\title{
The economic diplomacy of Poland - the origin and evolution of the organisational model and tasks during the transformation period
}

So far, broadly-understood economic diplomacy has rarely been addressed in Polish literature. Considering that at least for several decades the organisation of diplomacy has played an increasingly important role in the development of international economic links, it seems justified to view the issue from the perspective of Poland. The article attempts to give structure to a certain chaos in definitions. Its significant contribution seems to be the presentation of major findings from the analysis aimed at outlining the origin and evolution of the organisational model of economic diplomacy in Poland, with a special focus on the period of transition. The study is based on the hypothesis that, in spite of various efforts to adjust the organisational model, tasks, and functions of economic diplomacy to the requirements of the modern economic environment, it is still difficult to speak of its organisational consistency and measurable business-oriented effectiveness. The article ends with a summary of the most important conclusions from the analysis performed.

Keywords: economic diplomacy, commercial diplomacy, export promotion, organisation of diplomacy in Poland

JEL classification: F18, F55, M10

\section{Dyplomacja gospodarcza Polski - geneza oraz ewolucja modelu organizacyjnego i zadań w okresie transformacji}

Problematykę szeroko pojętej dyplomacji gospodarczej jak dotąd rzadko porusza się w polskiej literaturze. W sytuacji, gdy organizacja dyplomacji już od co najmniej kilku dekad odgrywa istotną i coraz ważniejszą rolę w kształtowaniu międzynarodowych powiazań gospodarczych, uzasadnione wydaje się spojrzenie na ten problem z polskiej perspektywy. $\mathrm{W}$ artykule podjęto próbę uporządkowania pewnego chaosu definicyjnego. Ważną jego częścią wydaje się prezentacja najważniejszych wyników analizy zmierzającej do nakreślenia genezy oraz ewolucji modelu organizacyjnego dyplomacji gospodarczej w Polsce, ze szczególnym uwzględnieniem okresu transformacji. $W$ badaniu przyjęto hipotezę, że mimo podejmowania wielu prób dopasowania modelu organizacyjnego, zadań i funkcji dyplomacji gospodarczej do wymogów współczesnego otoczenia gospodarczego, nadal trudno mówić o jej spójności organizacyjnej i wymiernej -

1 In 1991-2001, the Author was the head of the Economic and Commercial Section at the Embassy of the Republic of Poland in Budapest (initially as the commercial counsellor and from 1997 as the minister plenipotentiary). 
z punktu widzenia biznesu - skuteczności. Artykuł kończy zestawienie najważniejszych wniosków wynikających z przeprowadzonej analizy.

Słowa kluczowe: dyplomacja gospodarcza, dyplomacja handlowa, promocja eksportu, organizacja dyplomacji w Polsce

Klasyfikacja JEL: F18, F55, M10

\section{Introduction}

Being one of the oldest international activities, diplomacy dates back to the beginnings of human civilisation. It arose from the need to defend interests and rights as well as to ensure peaceful co-existence between countries. Although honoured by centuries-old traditions and practices, its forms, institutional organisation, methods, and tools have evolved along with the development of the state and the complexity of the international environment [Molendowski, Polan, 2007, p. 9].

Posing new challenges to the foreign service of every state, globalisation has significantly contributed to the separation from public diplomacy of a new form of diplomacy - economic diplomacy. It encompasses comprehensive communication on a regular basis between individual countries in order to maximise national benefits in various areas and activities such as trade, investment, and other types of economic relations [Rana, 2007; Marchewka-Bartkowiak, Musiałkowska, 2015].

For most countries, one of the key priorities of economic and foreign policies has become support from the public administration for enterprises operating in or entering international markets. The above trend, even though significantly delayed, has also materialised in Poland. The objective of this paper is an attempt to structure the existing terms and definitions. The article also presents the most important findings from the analysis aimed at outlining the origin and evolution of the organisational model of economic diplomacy in Poland, with a special focus on the period of transition.

\section{Economic diplomacy - origin and evolution}

An integral part of present-day international economic relations is trade, the carrier of economic progress that gave rise to economic diplomacy. The earliest reference to it dates back to 1453, assumed to be the time when diplomatic endeavours first began to concentrate on economic matters. It concerned the safeguarding of commercial interests and the conclusion of economic agreements by the Italian city-states, intermediaries in merchandise trade between Europe, the Middle East, the Far East, and Africa [Pietkiewicz, 1990, pp. 14-15]. 
According to Sokolnicki [1931, p. 450], economic interest appeared in international affairs relatively late, at the turn of the $20^{\text {th }}$ century. He believes the breakthrough point to be the first engagement of the US in political affairs far beyond the American continent in the last years of the $19^{\text {th }}$ century. It meant the abandonment of the Monroe Doctrine stated by US President James Monroe in 1823. From that time, economic reasons underlay a significant number of conflicts breaking out in the world and treaties concluded.

The traditional perception of international relations and foreign policy priorities came to an end along with that of the Cold War and the collapse of the Soviet Union. The latter development shook the belief that the power and international position of a state was determined by its military potential and supported the view on the power of a state identified with its economic potential [Hryniewiecki, Borońska, 2010, pp. 111-122].

An excellent example illustrating the ongoing process of the economisation of foreign affairs was the policy pursued by the US Federal Government in the 1990s. Undoubtedly, one of the greatest attainments of the Clinton Administration was the successful combination of the US foreign policy with its national economy and job creation policy. The primary task of his administration was to use all diplomatic means necessary to open new markets to US products, aimed at job creation and recovery of the US economy after recession [Paulsen, 1999, pp. 45-54].

Therefore, in addition to public diplomacy, in the late $20^{\text {th }}$ century economic diplomacy became one of the basic forms of modern diplomacy. It relies on public diplomacy in its main tools and means of executing tasks. It also constitutes a new tactic in implementing the strategy of promoting economic interests defined by the foreign policy objectives and guidelines. It reflects the process of the economisation and globalisation of international relations and the increasing role of trade links in building the power and image of a state in the international environment. It is worth mentioning that the separation of this form of diplomacy resulted from evolutionary, dynamic, and not imposed development of commercial linkages and an expanding scope of international economic interrelations rather than the implementation of artificial regulations [Molendowski, Polan, 2007, p. 41].

\section{The concept and substance of economic diplomacy}

Diplomacy comprises activities of the authorities and representations of a state abroad with the view to protecting and pursuing its external interests in a peaceful manner [Sutor, 2000, p. 29]. More broadly, diplomacy is also treated as a mechanism for representation, communication, and negotiation between states and other international players (entities, institutions) engaged in specific activities [Cohen, 1999, pp. 16-17]. 
In the scientific literature, the concept of economic diplomacy appeared in response to the need to name the process of economising the foreign service and activities of diplomats in an economic area.

Berridge and James [2001, p. 81] define economic diplomacy pursued by the ministry of foreign affairs and other ministries jointly competent for the international economic policy of a state as diplomacy relating to the pursuit and implementation of economic policy guidelines, e.g., activities of state representations and delegations to international economic organisations (such as the WTO, the $\mathrm{OECD}$, and the EU). Furthermore, economic diplomats conduct monitoring and submit relevant reports with regard to economic policies in other countries and serve as advisers for the development of the economic policy of their government.

Economic diplomacy also uses economic tools for implementing foreign policy, e.g., development aid and economic sanctions [Pinder, 1976, pp. 312-336]. There is also a broad interpretation treating not only states but also transnational corporations as players in economic diplomacy [Surmacz, 2008, p. 244].

In Polish literature, several terms with different meanings are used - "dyplomacja gospodarcza" [Krzymiński, 2002, pp. 171-174], "dyplomacja ekonomiczna" [Gawin, 2008, pp. 101-118], both translated as economic diplomacy, and "dyplomacja handlowa", commercial or trade diplomacy [Kunikowski, 2011, pp. 28-29]to signify diplomatic instruments of pursuing foreign economic policy; the method is a diplomatic (political) one but it serves economic purposes ${ }^{2}$. The emergence of the above-mentioned terms is connected with an increased importance of the economic factor to the present-day international relations and concepts of national security [Orzechowski, 2002, pp. 18-19].

The authors of the first Polish monograph on this subject define economic diplomacy as pursuing activities aimed at improving the international position of the state through broad promotion of its comprehensive economic interests (e.g. negotiation and signing of trade and other agreements, membership of international and regional economic organisations, etc.) and of particular interests of its individual entities (seeking foreign partners for domestic businesses, promoting national exporters, attracting foreign investment) by state representatives, i.e., professional economic diplomats [Molendowski, Polan, 2007, p. 64].

Therefore, economic diplomacy is identified with promotional measures taken by the diplomatic service in the interest of two different beneficiaries: (1) the state and its economy and (2) economic operators. Instruments employed in the former case include negotiation and conclusion of international (bilateral and multilateral) international agreements concerning trade, investment protection

2 According to Dumała [2013, p. 253], it is an understanding limited in scope; another definition of economic diplomacy found in the foreign literature includes also, or even primarily, economic tools for implementing foreign policy, e.g., development aid and economic sanctions. 
and support, elimination of double taxation, and membership of international organisations, whether universal (e.g. the WTO, the OECD, the World Bank) or regional (e.g. the EU). As regards activities carried out for the benefit of economic operators, those comprise seeking foreign partners, promoting export, and attracting foreign direct investment. The objectives of diplomacy understood as above include economic development, improving the competitiveness of the global economy, as well as increasing the wealth and well-being of the state and its citizens [Dumała, 2013, p. 254].

According to Hryniewiecki and Borońska [2010, pp. 111-122], economic diplomacy is a tool for the implementation of the foreign economic policy of a state maintaining permanent interactions with other entities performing diplomatic functions in the international environment. Such a line of reasoning leads to a new definition of economic diplomacy, taking into consideration specific characteristics of modern international relations and the essence of diplomacy itself. Therefore, economic diplomacy will be understood as follows: "activities of specialised state structures aimed at implementing the foreign economic policy of the state, consisting in the promotion of broad economic and political interests. The environment for such activities is a certain network of intermingled economic and political spheres, the public and private sectors, as well as multiple players co-existing and representing various (sometimes convergent) interests" [Hryniewiecki, Borońska, 2010, pp. 111-122].

The high rank of economic diplomacy is also emphasised by Krzymiński [2002, p. 171]. He sees economic diplomacy as a type of behavioural art, aimed at building national wealth and the well-being of all social groups and intended to perform two main functions:

- the recognition of the global economic environment of the state, its observation relying on scientific methods and logical thinking, as well as suggesting directions for designing and implementing the national strategy in a broad context of the world economy based on structured facts and trends,

- discrete and open co-participation in the implementation of the foreign part of the national strategy by negotiating optimal institutional and economic terms and conditions for specific entrepreneurial (commercial and industrial) activities, supporting them abroad and - after analysing them from various points of view - drawing conclusions for improvement and innovation.

Certain researchers studying economic diplomacy additionally distinguish commercial diplomacy [Saner, Yiu, 2003, pp. 2-31]. By fostering economic growth, governments help and promote domestic businesses, e.g., through export-support policies, legal advice, direct assistance in setting up foreign branches, as well as promoting foreign investment. According to Bergeijk [1994, pp. 81-82], such activities of state authorities constitute the main area of commercial diplomacy. 
Commercial diplomacy therefore ought to be oriented towards commercial policy measures connected with the negotiation of commercial contracts, resolution of trade disputes, and business support services [Kostecki, Naray, 2007, pp. 4-42].

In the Polish language, the terms "dyplomacja ekonomiczna" and "dyplomacja gospodarcza" are used interchangeably to signify economic diplomacy but often in contrast to "dyplomacja handlowa" (commercial diplomacy). In addition, various documents prepared by the Ministry of Foreign Affairs (MSZ) also contain phrases such as "ekonomizacja dyplomacji" (economisation of diplomacy) and "ekonomizacja polityki zagranicznej" (economisation of foreign policy).

Economic diplomacy seems to mostly have a macroeconomic (state) dimension, whereas commercial diplomacy should serve to achieve microeconomic (operating) objectives. However, it is clearly emphasised that in practice it is difficult to separate the tasks of economic diplomacy from those of commercial diplomacy, therefore their close coordination is of the essence [Marchewka, 2014, p. 2].

\section{Economic diplomacy in Poland}

\subsection{The beginnings of Polish economic diplomacy}

During the Second Polish Republic, diplomats served the country well by fulfilling their duties and tasks with full commitment and engagement, managing Poland's affairs and international relations, both political and economic. The ministers ensured that the economic tasks of the ministry competent for foreign affairs and its missions should be of essential importance, in both central and local operations. The robust growth in Polish exports observed in that period also resulted from close cooperation of the Polish business sector with the diplomatic units of MSZ. Moreover, commercial counsellors, then considered to be the "right hands" of the ambassadors or envoys, indeed prepared advantageous framework terms for treaties and political links as well as for effective pro-Polish lobbying, but they first and foremost arranged outlets for domestic producers [Łossowski, 1992; Krzymiński, 2002].

In the post-war years, the developed model of economic diplomacy in Poland deeply changed as a result of the inclusion of Poland in the USSR sphere of influence. Characteristically, in the economies of the former socialist countries, including Poland, foreign trade was controlled by the state. It was reflected in the creation of special authorities, bodies, and institutions established for the purpose of implementing the principle of the so-called state monopoly on foreign trade. A major role in foreign trade activities was played by commercial counsellors. They somewhat automatically took over most tasks connected with determining foreign trade flows. 
The whole burden related to the execution of the tasks of economic diplomacy was on commercial counsellors and their offices, formally included in their respective diplomatic missions but in terms of substance, administration, and budget reporting to MSZ. In the period in question, the hierarchical subordination of the institutions connected with the execution of economic diplomacy tasks shifted towards the ministry competent for the economy, which largely limited the previously leading role of MSZ in shaping economic relations with the foreign sector.

The situation remained unchanged in the first years after 1989, as in the period concerned none of the governments adopted an export-oriented approach; Skubiszewski, the minister in charge of foreign affairs in 1990-1993, was even criticised for the supposed abandonment of building economic relations by MSZ. It was reflected in giving no priority to economic diplomacy, lack of relevant strategies or structures, as well as neglecting its importance in the authority competent for foreign affairs of the Third Polish Republic [Krzymiński, 2002, p. 177].

\subsection{The 1999 reform of commercial counsellor offices and the establishment of economic and commercial sections}

Since new foundations for the functioning of the economy were created after 1989 , the role and functions of commercial counsellor offices needed to be reviewed. In July 1999, an agreement between the Minister of Foreign Affairs and the Minister of Economy laid down new rules and organisation of economic and commercial agencies abroad. Commercial counsellor offices were replaced by economic and commercial sections (abbreviated in Polish as WEH), functioning within the relevant diplomatic missions and consular posts. They took over the tasks concerning economic relations as well as the protection and promotion of economic interests of the Republic of Poland abroad. Pursuant to the act of 21 June 1996 on the office of the Minister of Economy, WEH remained economic and commercial structures substantively subordinate to the Ministry of Economy.

Economic and commercial sections were diplomatic missions, therefore their managers and employees were included in the foreign service of the Republic of Poland, pursuant to the Foreign Service Act of 27 July 2001. It must be added that the Ministry of Economy was not fully autonomous in this respect as WEH employees leaving to serve at a mission were granted their diplomatic status and ranks with the consent of MSZ [Szczepanik, 2002, pp. 432-448].

In the period in question, 81 economic and commercial sections operated under the supervision of the Ministry of Economy. As regards their substance, functions, and personnel, they were supervised by the Ministry of Economy, although their employees, as public officials included in the Polish foreign service and acting in the country of office, reported to the ambassador. From the 1999 reform of 
commercial counsellor offices, the economic and commercial sections of Polish embassies became the core of Poland's economic diplomacy.

The tasks of economic and commercial sections can be described as activities aimed at promoting Polish economic interests in the territory of the relevant country of office. Such a general description comprises, i.a., typical economic diplomacy measures, in particular with regard to the functioning of Poland in the EU, bilateral relations, or economic analyses. It must be remembered that the phrase export promotion is very broad and covers a variety of matters and problems, concerning both the protection of interests of Polish economic operators in the country of office and micro-scale promotion, frequently consisting in matching undertakings interested in establishing commercial relations, market analyses, identifying market niches, etc. ${ }^{3}$

In addition, activities of economic and commercial sections comprised creating Poland's image as an attractive business partner, encouraging investment, and fostering exports of Polish products and services to foreign markets. The functioning of WEH was also consistent with the execution of the fundamental tasks of the central administration, e.g., the maintenance of the country's high economic growth rate, improving the competitiveness of the Polish economy and Poland's accession to the EU.

\subsection{The new model of economic diplomacy in light of the agreement of the Ministers of Foreign Affairs and of Economy dated February 2006}

As already mentioned above, the organisation model of economic and commercial sections introduced in Poland from 1999 resulted from a compromise reached by the ministries competent for foreign affairs and the economy. However, the discussion on the model of Polish economic diplomacy was not over.

MSZ was aiming to take over from the Ministry of Economy a major part of matters relating to economic relations with the foreign sector and ultimately include economic and commercial sections in the embassy structures. On the other hand, experts from the Ministry of Economy claimed that the discussed concept of carrying out economic promotion abroad through market-based institutions such as the Export Promotion Institute or Agency would not ensure efficient and effec-

3 It was assumed in the Government Economic Strategy approved in January 2002 that the fostering of Poland's economic interests abroad would involve the whole foreign service and not only the commercial service; the main assessment criterion would be the effectiveness of promoting exports, attracting foreign investment, and defending Polish businesses against trade restrictions and limitations. Furthermore, any diplomatic mission would have a major task of constantly checking whether or not exports of Polish products and services were subject to barriers inconsistent with the international trade regulations or with the rule of reciprocity [Kozerski, 2002, p. 3]. 
tive functioning of the system supporting Polish businesses, mostly small and medium-sized enterprises, in their expansion to foreign outlets.

In 2006, the government decided to re-organize the Polish model of economic diplomacy. The framework for the changes introduced was adopted under the Agreement of 7 February 2006 between the Minister of Economy and the Minister of Foreign Affairs on the establishment of economic diplomacy. It resulted in the creation of economic diplomacy functioning within the structures of the Ministry of Foreign Affairs and responsible for handling international needs of all the ministries and government agencies dealing with various economic matters.

One consequence of the Agreement of 6 February 2006 was supposed to be the separation of different functions of foreign missions and posts: analyses, performed for the administration, and pure promotional activities, for the benefit of enterprises and their organisations. Therefore, the Agreement provided for the creation of two types of entities supporting Poland's foreign economic policy:

- Economic Sections (Wydziały Ekonomiczne - WE), subordinate to the Ministry of Foreign Affairs and executing the tasks of the Ministry of Economy and other economic departments, material to international interests of the state,

- Trade and Investment Promotion Sections (Wydziały Promocji Handlu i Inwestycji - WPHI), subordinate to the Ministry of Economy and carrying out professional activities for Polish business.

According to the 2006 arrangements made by the Ministers of Economy and of Foreign Affairs, the majority of the existing Economic and Commercial Sections were to be transformed into the Economic Sections of the Embassies. However, on 1 July 2006, under relevant regulations on budget entities and on the basis of the previous economic and commercial sections, the Minister of Economy established 45 Trade and Investment Promotion Sections (whose number showed minor changes in the following years). It meant that the tasks of economic diplomacy at foreign missions would be executed by sections subordinate to two different institutions, i.e., the Ministry of Foreign Affairs and the Ministry of Economy.

The main powers and tasks of Trade and Investment Promotion Sections were as follows [Molendowski, 2007, pp. 198-199]:

- provision of information on the ways of, opportunities for, and barriers to pursuing economic activities in the market of the country of office,

- assessment of the economic situation in terms of possible expansion of Polish enterprises in the market concerned,

- analyses of the competitiveness of Polish products and services and of local customer and consumer opinions on Polish products,

- facilitation of establishing relationships between business partners,

- provision of information on possible financial assistance in the implementation of promotional projects in the market of the country concerned. 
As regards the Economic Sections, their main tasks comprised the following [Dumała, 2013, pp. 268-269]:

- identification of economic problems of strategic importance to economic security,

- analysing of regional trade and investment cooperation,

- building of economic relations with priority countries and regions (still poorly recognised by enterprises),

- handling of bilateral and multilateral government negotiations,

- assisting in trade dispute resolution,

- economic promotion of the state and fostering interests of Polish businesses.

Assessments of the effects of the reform were extremely differentiated. The legal basis for the agreement establishing economic diplomacy was disputed. Many critics were of the opinion that the (institutional and functional) separation of instruments for attaining the objectives of Poland's foreign economic policy was artificial and that the created structures resulted in overlapping activities, thus in unjustified, unreasonable, and mutually competitive positions. There was even a very serious allegation of leading to corporate interests of MSZ officials being set above the state interest (for more information see: [Dumała, 2013, pp. 270-271]).

There were also different opinions. According to Szczerski (the then UnderSecretary of State at MSZ), the high engagement of diplomacy in the execution of tasks related to representing and defending the economic interests of the Republic of Poland abroad was confirmed by its significant analytical and information activities and supporting promotional measures [Sejm RP, 2007].

As stated by Wiśniewski, the then Deputy Minister at MSZ and the Government Plenipotentiary for the economisation of the foreign service and the comprehensive reform of the system of promoting the country abroad, in his speech given at the conference on the role of the engagement of public institutions in the economic promotion of Poland and regions in 2006, the economic service at MSZ would gradually influence the process of the economisation of the whole foreign service, introducing economic matters to the very centre of decisions concerning the Polish foreign policy.

According to the Deputy Minister, economic diplomacy was supposed to become - in addition to the planned government agency for economic promotion one of the two main pillars for pursuing the international economic interests of Poland. The intended mission of economic diplomacy was not only to prepare theoretical analyses and charts. In various places worldwide, it was supposed to be at the forefront of classical economic promotion, oriented towards the interest of an individual enterprise. However, the main difference would be that the fundamental point of reference for economic diplomacy was the national interest and needs of Poland and the partners were public institutions of other countries. 
Based on the above guidelines, MSZ planned to increase the number of countries with at least a minor representation of Polish economic diplomacy by the end of 2006 by around a dozen. The number of such states was supposed to be around 80 [Wiśniewski, 2006, p. 4].

To recapitulate, it must be agreed that a major problem in the practical implementation of economic diplomacy in Poland is, undoubtedly, the fact that the 2006 reform is incomplete. An important element was supposed to be an economic promotion agency, never actually established. It was intended to be an agency supervising the created Trade and Investment Promotion Sections, ultimately transformed into its foreign branches. As emphasised by the Association of Polish Exporters (Stowarzyszenie Eksporterów Polskich) in the document entitled "The strategy for export-oriented development of the Polish economy" (Strategia proeksportowego rozwoju gospodarki polskiej) published in October 2008, due to the absence of such an agency, the promotional activities carried out by a number of institutions were not synchronised, thus less effective and efficient, whereas the increasing "atomisation" of the promotion and support system, lacking an institution to coordinate such activities, must be regarded as its essential weakness.

\section{Conclusions}

Economic diplomacy developed within modern diplomacy is a response to the challenges of present-day trends in the world economy. The globalisation of international relations and the increased role of trade links in building the image and position of a state in the international environment requires appropriate tools and instruments. That fact is almost universally taken into account in the organisation of diplomatic services of all countries worldwide. For a longer time now, the relevant issues have been addressed in a number of analyses, mostly carried out by foreign experts. Also in Poland, in addition to the first (and the only one so far) monograph, published in 2007 [Molendowski, Polan, 2007], recent years have seen certain very valuable articles and studies on that subject.

In Poland, economic affairs were an important element of diplomatic activities as early as the first years after regaining independence. The buoyant growth in exports in the interwar period clearly confirmed the effectiveness of measures taken at that time. The inclusion of Poland in the USSR sphere of influence after World War II was reflected in the establishment of special institutions (also functioning abroad) responsible for the implementation of the state monopoly on foreign trade. The lack of strategies and structures to support an export-stimulating orientation of the economy was also characteristic of the first years of transition. 
Efforts to ensure greater coordination and cooperation between diplomatic missions proved a certain success as late as after the mid-1990s. They resulted in the creation of Economic and Commercial Sections of the Embassies of the Republic of Poland in more than 80 countries. The sections in question, functioning under the substantive supervision of the Ministry of Economy, were granted broad powers to take in their respective countries of office any actions aimed at promoting and supporting the economic interests of Poland. Advantageously (it is worth adding that such solutions are applied in most EU member states and in the US), it ensures the concentration of all economic diplomacy tasks in a single competent institution.

The organisation model of economic and commercial sections introduced in 1999 resulted from a compromise reached by the ministers competent for foreign affairs and the economy. Afterwards, the solution was very frequently contested by representatives of both ministries. Economic operators pointed to the need for improvements as well. At the beginning of 2006, it was decided to divide powers concerning broad economic diplomacy between the ministries competent for foreign affairs and for the economy. As a result, the Economic and Commercial Sections were eliminated. They served as the basis for the creation in around 45 countries of Trade and Investment Promotion Sections in charge of direct promotion of the economy and support for exporters. At the same time, the Minister of Foreign Affairs undertook to set up more than 80 Economic Sections, responsible for macro-scale economic diplomacy. To that end, he "took over" from the Ministry of Economy around 300 jobs and more than $50 \%$ of budget appropriations used by WEH. Unfortunately, in the following 10 years the Minister of Foreign Affairs did not create such sections. In most countries, there are only units for economic affairs with 1 or 2 employees. Another promise not kept was the creation of a government agency responsible for the promotion of the Polish economy abroad, export development, and supporting investment (both foreign inward and outward).

At the end of 2016, another reform of the organisation of economic diplomacy in Poland was announced, within the framework of the Responsible Development Plan. One element is the creation of the Polish Investment and Trade Agency. The Agency is intended to supervise a network of Foreign Trade Offices (Zagraniczne Biura Handlowe - ZBH), with the target number of around 70. The Offices are supposed to be created on the basis of the previously functioning Trade and Investment Promotion Sections. $\mathrm{ZBH}$ will be set up in countries characterised by the greatest development potential for Polish businesses. Their main task is to provide professional services to Polish enterprises interested in expansion in foreign markets. But the Offices will function outside the embassy structures, and therefore have no diplomatic status. The solution means that the 
Minister of Economy withdraws from participation in economic diplomacy. Therefore, only the Ministry of Foreign Affairs will remain in this field of activity. Considering that for more than 10 years it took no care of according appropriate importance to economic diplomacy, it seems justified to be concerned that, after almost 30 years from the beginning of transition, in the period to come Poland will still have no professional and comprehensive economic diplomacy.

The analysis presented in the article unambiguously suggests that in the period of transition Polish economic diplomacy came to play an increasing role in the functioning of the state. It gave rise to extensive discussion on its tasks, shape, framework, and organisation. Every now and then, there were more or less effective attempts to introduce a consistent and most effective model of economic diplomacy. Unfortunately, it does not follow from the recently announced changes that they may indicate radical improvement.

\section{Acknowledgements, sources of financing}

The publication was co-financed from funds allocated to the Faculty of Economics and International Relations at the Cracow University of Economics as a subsidy for maintaining the research capacity.

\section{References}

Berridge G., James A., 2001, A dictionary of diplomacy, Palgrave Macmillan, Hampshire.

Cohen R.,1999, Reflections on the new global diplomacy: Statecraft 2500 BC to 2000 AC, [in:] Innovation in diplomatic practice, ed. J. Melissen, Palgrave Macmillan, London.

Dumała H., 2013, Dyplomacja ekonomiczna RP - założenia i realizacja, [in:] Nowe oblicza dyplomacji, ed. B. Surmacz, Wydawnictwo UMCS, Lublin.

Gawin G., 2008, Ksztaltowanie się i rola dyplomacji ekonomicznej w Polsce, Polski Przegląd Dyplomatyczny, no. 3.

Hryniewiecki R., Borońska K., 2010, Dyplomacja gospodarcza jako nowe narzędzie polityki zagranicznej państwa, [in:] Ekonomia 12 - Problemy globalizacji, ed. J. Rymarczyk, Wydawnictwo Uniwersytetu Ekonomicznego, Wrocław.

Kostecki M., Naray O., 2007, Commercial diplomacy and international business, Discussion Papers in Diplomacy, Netherlands Institute of International Relations, Clingendael, http:// www.clingendael.nl/sites/default/files/20070400_cdsp_diplomacy_kostecki_naray.pdf [access: 10.07.2017].

Krzymiński A.H., 2002, Dyplomacja gospodarcza, [in:] Dyplomacja, ed. M. Wilk, Wyższa Szkoła Studiów Międzynarodowych, Łódź.

Kunikowski J., Turek A., 2011, Bezpieczeństwo i dyplomacja. Słownik terminów, Wyższa Szkoła Nauk Społecznych, Warszawa.

Łossowski P., 1992, Dyplomacja Drugiej Rzeczpospolitej. Z dziejów polskiej stużby zagranicznej, Wydawnictwo Sejmowe, Warszawa.

Marchewka-Bartkowiak K., 2014, Dyplomacja ekonomiczna w Polsce-organizacja, zadania i kierunki działalności, Analizy BAS, no. 6. 
Marchewka-Bartkowiak K., Musiałkowska I., 2015, Dyplomacja handlowa w krajach Unii Europejskiej jako przykład wspótpracy administracji i przedsiębiorstw, Studia BAS, no. 1.

Molendowski E., Polan W., 2007, Dyplomacja gospodarcza. Rola i znaczenie w polityce zagranicznej państwa, Wolters Kluwer Business, Kraków.

Orzechowski M., 2002, Nowoczesna dyplomacja (geneza, ewolucja, istota, charakter, rola), [in:] Dyplomacja, ed. M. Wilk, Wyższa Szkoła Studiów Międzynarodowych, Łódź.

Paulsen T., 1999, Economic Diplomacy. Die Ökonomisierung der amerikanischen Außenpolitik unter Präsident Clinton, Springer Verlag, Wiesbaden.

Pinder J., 1976, Economic Diplomacy, [in:] World Politics. An Introduction, eds. J. N. Rosenau, K.W. Thompson, G. Boyd, Macmillan., New York.

Rana S.K., 2007, Economic diplomacy: The experience of developing states, [in:] Bayne N., Woolcock S., The new economic diplomacy, Ashgate Publishing. Hampshire.

Saner R., Yiu L., 2003, International Economic Diplomacy: Mutations in Post-modern Times, Discussion Papers in Diplomacy, no. 84, Netherlands Institute of International Relations "Clingendael", http://www.diplomacydialogue.org/images/files/20030109-DP-DSP.pdf [access: 10.07.2017.].

Sejm RP, 2007, Odpowiedź podsekretarza stanu w Ministerstwie Spraw Zagranicznych - z upoważnienia ministra - na interpelacje nr 8904, http://orka2.sejm.gov.p1/IZ5.nsf/main/ 33DD7A0F [access: 10.07.2017.].

Surmacz B., 2008, Dyplomacja w późno westfalskim ładzie międzynarodowym, [in:] Późno westfalski tad międzynarodowy, ed. M. Pietraś, K. Marzęda, Wydawnictwo Uniwersytetu Marii Curie-Skłodowskiej, Lublin.

Surmacz B. (ed.), 2013, Nowe oblicza dyplomacji, Wydawnictwo UMCS, Lublin.

Sutor J., 2000, Prawo dyplomatyczne i konsularne, Wydawnictwa Prawnicze PWN, Warszawa.

Szczepanik K., 2002, Organizacja i funkcjonowanie stużby dyplomatyczno-konsularnej, [in:] Polityka zagraniczna RP 1989-2002, ed. R. Kuźniar, K. Szczepanik, Wydawnictwo Askon, Warszawa.

Wiśniewski R., 2006, Rola i zaangażowanie instytucji publicznych w promocję gospodarcza Polski i regionów, http://www.paiz.gov.pl/files/?id_plik=7520 [access: 10.07.2017)].

E. Molendowski (®) edward.molendowski@uek.krakow.pl

Uniwersytet Ekonomiczny w Krakowie, ul. Rakowicka 27, 31-510 Kraków, Polska 